\title{
Analisis Deiksis Waktu pada Tuturan Dosen yang Berlatar Belakang Budaya Berbeda
}

\section{Deixis Analysis Time on Lecture Speech with Different Cultural Background}

\author{
Desy Irafadillah Effendi*, Maya Safhida, Joko Hariadi \\ Pendidikan Bahasa Indonesia, Universitas Samudra, Langsa, Indonesia \\ ${ }^{*}$ Corresponding Author, Email: desyirafadillah@yahoo.co.id
}

\begin{abstract}
Abstrak
Tuturan dosen FKIP Universitas Samudra yang mengandung deiksis sering salah ditafsirkan oleh mahasiswa. Kesalahtafsiran tersebut berkaitan dengan pemahaman makna tuturan/ujaran dengan acuannya. Salah satu faktor penyebab kesalahtafsiran itu adalah latar belakang budaya yang berbeda sehingga mempengaruhi bentuk-bentuk bahasa yang digunakan. Hal ini mengakibatkan komunikasi tidak berjalan sesuai dengan yang diharapkan. Berdasarkan hal tersebut, permasalahan dalam penelitian ini adalah mengetahui bagaimanakah deiksis waktu pada tuturan dosen FKIP yang berlatar belakang budaya berbeda di Universitas Samudra. Sumber data dalam penelitian ini adalah dosen FKIP yang memiliki latar belakang budaya berbeda dan data yang mengandung diambil pada saat proses perkuliahan berlangsung dan didokumentasikan dalam bentuk rekaman. Adapun tuturan dosen yang dimaksud adalah tuturan dosen yang berlatar budaya Minangkabau, Tapanuli Selatan, dan Jawa Tengah. Selanjutnya, data tersebut diklasifikasi berdasarkan deiksis waktu, kemudian dianalisis dan disimpulkan. Dari hasil penelitian ini ditemukan bentuk deiksis waktu dosen Minangkabau adalah kemarin itu, nanti siang, munggu lalu, minggu yang lalu, tadi, nanti, kemarin, dan sekarang. Dosen yang berlatar belakang budaya Tapanuli Selatan adalah sekarang, nanti, hari ini, bulan depan, minggu depan, dan kemarin sore. Dosen yang berlatar belakang budaya Jawa adalah hari ini, kemarin, nanti, sekarang, minggu depan, dan dari tadi.
\end{abstract}

Keyword: deiksis persona, deiksis ruang, dan deiksis waktu

\begin{abstract}
Faculty instructors FKIP University of Samudra containing deiksis often misinterpreted by students. The misinterpretation is related to understanding the meaning of speech / speech with reference. One of the factors causing misinterpretation is the different cultural backgrounds that affect the forms of language used. This resulted in communication not running as expected. Based on this, the problem in this research is to find out how the time deiksis in the speech of FKIP lecturers with different cultural background in the University of Samudra. Sources of data in this study are FKIP lecturers who have different cultural backgrounds and the data contained taken at the time of the lecture process took place and documented in the form of recording. The lecturers 'speeches are lecturers' speeches from Minangkabau, South Tapanuli and Central Java. Furthermore, the data is classified based on the time dextis, then analyzed and inferred. From the results of this study found the form of deiksis time Minangkabau lecturers are yesterday, later afternoon, munggu ago, last week, earlier, later, yesterday, and now. A lecturer with a South Tapanuli cultural background is now, later, today, next month, next week, and yesterday afternoon. A lecturer with a Javanese cultural background is today, yesterday, later, now, next week, and from before. Keyword: deiksis persona, deiksis space, and deiksis time
\end{abstract}

How to Cite: Effendi, D.I., Maya S., Joko H., (2018), Analisis Deiksis Waktu pada Tuturan Dosen yang Berlatar Belakang Budaya Berbeda, SIMBOLIKA, 4 (1): 52-61. 


\section{PENDAHULUAN}

Bahasa mempunyai peranan yang penting dalam kehidupan manusia. Fungsi bahasa adalah sebagai alat komunikasi bagi manusia, baik secara lisan maupun tulisan. Melalui bahasa, manusia dapat mengungkapkan ide, maksud, dan perasaannya kepada orang lain. Jadi, dengan adanya bahasa, manusia dapat menerima informasi antarsesamanya.

Tuturan (ujaran) merupakan bentuk komunikasi lisan yang digunakan oleh penutur dan lawan tutur. Sebuah tuturan tentunya mengandung tujuan dan makna tertentu. Tujuan dan makna yang terkandung dalam tuturantersebut harus dipahami oleh lawan tutur sesuai dengan tujuan dan maksud seorang penutur. Hal ini sangat penting agar komunikasi dapat berjalan dengan baik.

Sebuah komunikasi tidak berlangsung dalam ruang hampa sosial, melainkan dalam konteks atau situasi tertentu. Secara luas, konteks di sini berarti semua faktor di luar orang-orang yang berkomunikasi.Menurut Rustono (1999:20), konteks adalah sesuatu yang menjadi sarana penjelas suatu maksud. Tanpa memperhatikan konteks makna itu tidak dapat dipahami.Oleh karena itu, makna sebuah tuturan baru dapat dimengerti ketika dikaitkan dengan konteks tuturan agar komunikasi dapat berjalan lancar.

Dalam berkomunikasi, penutur sering menggunakan kata-kata yang merujuk kepada sesuatu, yang disebut sebagai deiksis. Deiksis yang menjadi salah satu bidang kajian ilmu pragmatik tersebut, oleh Kushartanti (2005:111), diartikan sebagai cara merujuk kepada suatu hal yang berkaitan dengan konteks penutur. Sementara dalam KBBI (2002: 245), deiksis diartikan sebagai hal atau fungsi menunjuk sesuatu di luar bahasa; kata yang mengacu kepada persona, waktu, dan tempat suatu tuturan. Jadi, deiksis merupakan ungkapan yang terikat dengan konteksnya.

Sebagaimana yang kita ketahui, fungsi utama bahasa adalah alat untuk menyampaikan pesan dari penutur kepada lawan tutur. Fungsi bahasa ini sangat penting ketika seorang dosen ingin menyampaikan maksudnya dalam proses pembelajaran. Oleh karena itu, pemahaman tentang konteks harus dimiliki oleh pemakai bahasa dalam menafsirkan ujaran karena konteks dapat memperjelas sebuah tuturan yang disampaikan.

Apabila penutur salah menggunakan bentuk deiksis yang tepat saat berkomunikasi, hal tersebut akan membuat komunikasi yang dibangunnya menjadi terganggu. Sebagai contoh, kalimat Besok tugas ini harus sudah dikumpulkan di meja saya. Di dalam kalimat tersebut, terdapat beberapa kata yang mengandung deiksis, baik deiksis persona, deiksis ruang, maupun deiksis waktu. Kata besok termasuk ke dalam deiksis waktu. Apakah kata besok itu mengacu pada hari setelah hari ini atau minggu depan sesuai dengan jadwal perkuliahan. Kata saya merupakan deiksis persona. Kata saya merujuk kepada diri penutur. Seorang lawan tutur harus tahu siapa yang bertutur, apakah seorang dosen, guru, atau pengajar di sebuah bimbingan belajar. Kalimat tersebut baru dapat ditafsirkan sesuai dengan maksud penutur apabila lawan tutur berada pada situasi yang sama dengan penutur. Dengan kata lain, penutur harus mengetahui konteks pembicaraan. Pemberian makna tanpa memperhatikan konteks dapat menimbulkan tafsiran yang berbeda-beda. Oleh karena itu, makna sebuah tuturan hanya dapat diketahui bila sudah berada dalam peristiwa bahasa karena dipengaruhi oleh konteks situasi pembicaraan yang diacu oleh penutur.

Tuturan dosen yang mengandung deiksis di dalam proses perkuliahan, baik berupa deiksis persona, deiksis ruang, maupun deiksis waktu sering digunakan. Kebanyakan dari tuturan tersebut belum dapat dipahami secara tepat oleh mahasiswa. Masih terjadi kebingungan, ketidakjelasan, dan bahkan kesalahpahaman makna atau 
maksud oleh mahasiswa atas penggunaan deiksis dalam tuturan dosen. Kebingungan tersebut berkaitan dengan pemahaman makna tuturan/ujaran dengan acuan atau referennya.

Salah tafsir makna tuturan dosen tersebut tidak bisa dihindari mengingat dosen FKIP Universitas Samudra berasal dari berbagai daerah di luar Provinsi Aceh, seperti Sumatera Utara, Sumatera Barat, Sumatera Selatan, Jawa Barat, dan Yogyakarta. Perbedaan latar belakang budaya tersebut secara tidak langsung menghasilkan bentukbentuk bahasa yang berbeda pula, meskipun masih dalam konteks bahasa Indonesia.

Penelitian tentang deiksis sudah banyak dilakukan.Teguh Setiawan pada tahun 1992 menulis skripsi yang berjudulAnalisis Deiksis Persona dalam Kumpulan Cerita Pendek Sri Sumarah Karya Umar Kayam.Dalam penelitian inihanya difokuskan pada deiksis persona. Tahun 2016, Teresia Noberty menulis skripsi dengan judul Fenomena Deiksis pada Rubrik Kolom di Harian Jawa Pos Edisi SeptemberDesember 2015. Penelitian ini membahasa wujud deiksis eksofora dan endofora yang terdapat pada rubrik kolom harian Jawa Pos tersebut. Penelitian tentang deiksis juga dilakukan oleh Nofitasari dalam skripsinya yang berjudul Deiksis Sosial dalam Novel Laskar Pelangi pada tahun 2012. Fokus penelitian ini adalah pada deiksis sosial.

Sejauh pengetahuan peneliti, penelitian terhadap deiksis yang terdapat pada tuturan dosen belum dilakukan. Penelitian terhadap deiksis yang digunakan oleh guru di sekolah sudah pernah dilakukan oleh Maya Safhida dalam tesisnya yang berjudul Analisis Deiksis Tuturan Guru dalam Pembelajaran di SD Negeri 16 Banda Aceh. Penelitian ini mengkaji deiksis persona, deiksis ruang, dan deiksis waktu pada guru kelas I dan II SD Negeri 16 Banda Aceh.

\section{METODE PENELITIAN}

Dosen FKIP Universitas Samudra berjumlah 87 orang dan tersebar di 10 program studi. Dari keseluruhan jumlah dosen tersebut,dosen yang dijadikan sumber data dalam penelitian ini hanya dosen berasal dari luar provinsi Aceh, yaitu dari Sumatera Utara, Sumatera Barat, Sumatera Selatan, Jawa Tengah, dan Yogyakarta. Data dalam penelitian ini adalah tuturan dosen FKIP Universitas Samudra yang mengandung deiksis persona, deiksis ruang, dan deiksis waktu. Data yang mengandung tuturan deiksis persona, ruang, dan waktu diambil pada saat proses perkuliahan berlangsung. Dosen yang dimaksud adalah dosen yang berlatar belakang budaya Minangkabau, budaya Tapanuli Selatan, dan budaya Jawa.Data tersebut diperoleh melalui perekaman sehingga merupakan data yang alamiah.

Metode yang digunakan dalam penelitian ini adalah metode deskriptif kualitatif. Metode deskriptif yaitu suatu metode dalam meneliti status kelompok manusia, obyek, suatu set kondisi, suatu sistem pemikiran ataupun suatu kelas peristiwa pada masa sekarang (Nazir, 2003: 54). Teknik pengumpulan data dilakukan dengan observasi. Teknik observasi yang digunakan adalah teknik observasi tak berpartisipasi (nonparticipant observasion), yakni peneliti tidak terlibat dan hanya sebagai pengamat independen (Sugiyono, 2007: 145). Dalam hal ini, peneliti hanya mengamati dan mencatat (merekam) setiap tuturan dosen serta memperhatikan situasi ketika tuturan tersebut berlangsung tanpa terlibat dalam proses perkuliahan.

Analisis data dilakukan dengan mengorganisasikan data, menjabarkan ke dalam unit-unit melakukan sintesis, menyusun ke dalam pola, memilih mana data yang penting dan akan dipelajari, dan membuat kesimpulan yang dapat diceritakan kepada orang lain (Sugiyono, 2008: 88).

\section{HASIL DAN PEMBAHASAN}

Deiksis merupakan salah satu bagian dari kajian pragmatik. Pragmatik adalah studi 
tentang makna yang disampaikan oleh penutur (atau penulis) dan ditafsirkan oleh pendengar (atau pembaca). Sebagai akibat studi ini lebih banyak berhubungan dengan analisis tentang apa yang dimaksud orang dengan tuturan-tuturannya daripada dengan makna terpisah dari kata atau frasa yang digunakan dalam tuturan itu sendiri. Pragmatik adalah kajian tentang penggunaan bahasa sesungguhnya. Pragmatik mencakup bahasan tentang deiksis, praanggapan, tindak tutur, dan implikatur percakapan.

Deiksis sebagai salah satu kajian dalam pragmatik, adalah kata yang tidak memiliki referen yang tetap (tetapi berubah-ubah) seperti kata saya, sini,dan sekarang. Misalnya, dalam dialog antara penutur A dan penutur B, saya secara bergantian mengacu kepada A atau B. Kata sini mengacu kepada tempat yang dekat dengan penutur, dan kata sekarang mengacu kepada waktu ketika penutur sedang berbicara.

Kata deiksis berasal dari bahasa Yunani, yakni deiktikos yang berarti hal penunjukan secara langsung.Sudaryat (2009:121) mengatakan bahwa deiksis adalah bentuk bahasa yang berfungsi sebagai penunjuk hal atau fungsi tertentu di luar bahasa.Dengan kata lain, deiksis pada dasarnya merupakan penunjukan melalui bahasa. Yule (2006:13) menambahkan bahwasanya bentuk-bentuk linguistik yang digunakan untuk menyelesaikan penunjukan tersebut disebut ungkapan deiksis.

Kaswanti Purwo (dalam Sumarsono, 2008:60) menyebut beberapa jenis deiksis, yaitu deiksis persona, tempat, waktu, dan penunjuk. Sementara Nababan (1987:41) membagi deiksis menjadi lima macam, yaitu deiksis persona, deiksis tempat, deiksis waktu, deiksis wacana, dan deiksis sosial.

Deiksis waktu ialah pemberian bentuk pada rentang waktu seperti yang dimaksudkan penutur dalam peristiwa bahasa. Dalam banyak bahasa, deiksis (rujukan) waktu ini diungkapkan dalam bentuk kala. Dieksis waktu adalah pemberian bentuk terhadap jarak waktu yang dipandang dari waktu ungkapan. Deiksis waktu mengacu pada tuturan si pembicara, apakah pada saat dia berbicara, sebelum atau sesudah tuturan. Menurut Lavinson (dalam Abdul Wahab: 2007) deiksis waktu dapat berwujud dalam bentuk leksikal ataupun gramatikal.

Deiksis waktu dapat diartikan sebagai pengungkapan jarak waktu ditinjau dari waktu ketika sebuah tuturan dihasilkan. Deiksis waktu disebut juga deiksis temporal. Patokan waktu dalam deiksis ini dilihat dari sudut pandang penutur. Penggunaan deiksis waktu yang terdapat pada tuturan dosen FKIP yang berlatar belakang budaya berbeda adalah sebagai berikut.

Berdasarkan data yang diperoleh, deiksis waktu yang ditemukan dalam tuturan dosen yang berlatar belakang budaya Minangkabau adalah kemarin itu, nanti siang, minggu lalu, tadi, nanti, sekarang, dan kemarin.Rujukan ungkapan-ungkapan tersebut berbeda-beda tergantung pada konteks tuturan. Berikut adalah data yang diperoleh menyangkut dengan deiksis waktu.

Jadi tugas-tugas yang kemarin itu udah dikumpul?

(1) Ya sudah, nanti siang aja ya.

(2) Jadi, beberapa minggu lalu sudah pernah kita bahas tentang kesetimbangan fasa ini.

(3) Apa tadi soalnya?

(4) Tadi Bapak suruh hitung ya.

(5) Kan tadi ada tiga sifat kan? Ada fraksimol, ada tekanan, ada suhu.

(6) Saya kemarin kita hentikan kalau dia sudah larut aja kan?

(7) Iya, jadi seperti apa nanti jika dia butuh empat variabel?

(8) Itu diturunkan dulu dari hukum hubungan apa kemarin itu?

(9) Tapi sekarang persamaan datarnya ditambahkan dengan faktor potensial itu ya.

(10) Beberapa minggu yang lalu sudah Bapak jelaskan juga tentang diagram fasa. 
(11) Nanti malam Bapak periksa semua tugas kalian.

(12) Hari ini saya beri latihan, jawab yang benar jangan asal-asal karena ini Bapak ambil untuk nilai kuis. Paham ya kalian?

(13) Kemarin itu sudah dijelaskan.

(14) Kemarin nomor lima tidak ada yang betul. Kenapa?

Deiksis waktu kemarin itu merujuk kepada waktu yang telah berlalu. Kata tersebut mengacu kepada beberapa waktu yang telah lalu saat dosen memberikan tugas yang dimaksud dalam tururan tersebut. Berdasarkan konteksnya, deiksis waktu kemarin itu tersebut patokan waktunya adalah satu atau dua minggu sebelum tuturan tersebut diujarkan. Seperti yang terlihat pada data berikut ini.

(1) Jadi tugas-tugas yang kemarin itu udah dikumpul?

(2) Itu diturunkan dulu dari hukum hubungan apa kemarin itu?

(15) Kemarin itu sudah dijelaskan.

Rujukan kemarin itu pada ketiga data di atas mengacu pada beberapa waktu yang lalu. Deiksis waktu tersebut merujuk pada hari ketika dosen memberikan tugas. Hari tersebut bertepatan dengan jadwal mata kuliah yang dimaksud. Pada data (1), penggunaan kemarin itu mengacu pada waktu yang sudah lama berlalu. Berdasarkan konteksnya, bentuk tersebut merujuk pada saat tugas-tugas tersebut diberikan oleh dosen. Bentuk kemarin itu pada data (9) mengacu pada hari kuliah ketika materi tersebut diberikan. Dengan demikian, bentuk tersebut dapat mengacu pada satu atau dua minggu sebelum tuturan. Selanjutnya, kemarin itu pada data (15) mengacu kepada waktu yang telah lama berlalu. Kata tersebut mengacu kepada beberapa waktu yang telah lalu saat dosen memberikan penjelasan terhadap materi yang dimaksud. Berdasarkan konteksnya, kemarin itu pada data (15) tersebut patokan waktunya tidak jelas, apakah satu minggu yang lalu, dua minggu yang lalu, atau pada awal semester.
Kata kemarin diartikan sebagai hari sebelum hari ini. Rujukan kata tersebut dapat berbeda-beda bergantung pada konteks tuturan. Penggunaan deiksis waktu kemarin diperlihatkan pada data berikut ini.

(16) Saya kemarin kita hentikan kalau dia sudah larut aja kan?

(17) Kemarin nomor lima tidak ada yang betul. Kenapa?

(18) Deiksis waktu kemarin pada data

(7) mengacu kepada beberapa hari sebelum tuturan itu diujarkan. Deiksis waktu tersebut mengacu kepada waktu dilakukan percobaan Kimia di laboratorium. Sesuai dengan konteksnya, kata kemarin tersebut merujuk kepada satu hari sebelum tuturan. Rujukan tersebut digunakan sesuai dengan rujukan waktu yang sebenarnya, yakni hari sebelum hari ini. Dengan demikian, waktu yang dirujuk pada data tersebut adalah waktu tertentu dan pasti.

Pada data (16), kata kemarin merujuk kepada beberapa hari sebelum tuturan. Waktu yang ditunjukkan memiliki rentang waktu yang lama, yakni beberapa minggu sebelum tuturan.

Kata nanti siang mengacu pada waktu yang akan datang setelah tuturan. Kata nantisiang tersebut merujuk kepada waktu siang setelah tuturan pada hari yang sama ketika tuturan itu berlangsung. Berdasarkan konteks tuturan, penggunaan nanti siang mempunyai jangkauan waktu sampai siang, seperti yang diperlihatkan pada data (2) berikut.

(2) Ya sudah, nanti siang aja ya.

Selain deiksis nanti siang, deiksis waktu juga ditunjukkan oleh kata nantidan nanti malamsebagaimana yang ditunjukkan pada data data (8) dan data (13) berikut ini.

(8) Iya, jadi seperti apa nanti jika dia butuh empat variabel?

Bentuk nanti yang dirujuk pada tuturan di atas menunjukkan waktu yang dekat ke depan, tidak lama sesudah tuturan diujarkan. 
Artinya, kata nanti mangacu pada waktu yang tidak lama dari sekarang. Penggunaan nanti pada konteks tersebut merujuk kepada beberapa menit sesudah tuturan. Tuturan tersebut dituturkan ketika dosen sedang menjelaskan materi kuliah.

(13) Nanti malam Bapak periksa semua tugas kalian.

Bentuk nanti malam pada data di atas merujuk pada waktu malam, yakni beberapa saat setelah tuturan setelah matahari terbenam (malam hari). Rentang waktunya adalah mulai dari terbenamnya matahari sampai terbit matahari.

Selanjutnya, hasil penelitian juga menunjukkan penggunaan deiksis waktu minggu lalu dan minggu yang lalu. Deiksis waktu ini menunjukkan waktu yang telah berlalu atau waktu setelah tuturan. Berdasarkan konteksnya, deiksis waktu tersebut merujuk pada waktu jadwal mata kuliah bersangkutan.

(3) Jadi, beberapa minggu lalu sudah pernah kita bahas tentang kesetimbangan fasa ini.

(11)Beberapa minggu yang lalu sudah Bapak jelaskan juga tentang diagram fasa.

Berikut adalah data yang menunjukkan penggunaan deisksi waktu tadi.

(3) Apa tadi soalnya?

(4) Tadi Bapak suruh hitung ya.

(5) Kan tadi ada tiga sifat kan? Ada fraksimol, ada tekanan, ada suhu.

Penggunaan kata tadi merujuk kepada waktu dekat ke belakang sebelum tuturan. Berdasarkan konteksnya, kata tadi tersebut mengacu kepada waktu yang belum lama berlalu sebelum tuturan dan masih pada hari yang sama. Dalam artian, kata tadi mengandung pengertian baru saja terjadi sebelum dosen mengujarkan tuturan tersebut, beberapa menit sebelum tuturan, seperti terlihat pada ketiga data di atas.

Kata sekarang merujuk pada waktu dituturkannya ujaran tersebut. Katasekarang dapat menunjuk pada hari saat tuturan itu berlangsung. dengan kata lain, sekarang menagcu pada waktu kini, saat tuturan berlangsung, seperti yang terlihat pada data berikut ini.

Tapi sekarang persamaan datarnya ditambahkan dengan faktor potensial itu ya.

(12) Sekarang penjelasan kenapa diagram fasa bentuknya seperti ituya, bisa dilihat di halaman 169.

Deiksis waktu hari ini merujuk kepada hari (waktu) sekarang saat tuturan tersebut diujarkan. Deiksis hari ini tersebut dapat juga merujuk kepada waktu tertentu dalam lingkup hari dituturkan ujaran. Bentuk deiksis waktu hari ini pada data (14) berikut mengacu pada waktu tuturan diujarkan. Rentang waktunya adalah selama jadwal kuliah tersebut berlangsung.

(14) Hari ini saya beri latihan, jawab yang benar jangan asal-asal karena ini Bapak ambil untuk nilai kuis. Paham ya kalian?

Data tuturan dosen FKIP yang berlatar belakang budaya berbeda dipaparkan sebagai berikut.

(1) Dan sekarang terbukti bisa lulus PNS dan kita berani mempertanggungjawabkan.

(2) Fakultas paling favorit dan paling cantik sekarang.

(3) Saya yakin di kelas ini, tidak semua, tentu nanti akan jadi guru.

(4) Dan nanti saya akan berusaha untuk soal ujian akhir kita lebih ke praktikal.

(5) Saya akhiri perkuliahan kita sore hari ini, mudah-mudahan ada manfaat yang kalian dapat.

(6) Saya tidak tahu semester depan atau bulan depan atau minggu depan saya masih dipercaya untuk mengajar di PGSD.

(7) Ya, izin. Kemarin sore di kampus.

Pada data di atas terlihat bahwa deiksis waktu yang terdapat dalam tuturan dosen FKIP yang berlatar belakang budaya Tapanuli Selatan adalah sekarang, nanti, hari ini, bulan depan, minggu depan, dan kemarin sore.Deiksis waktu sekarang digunakan untuk mengacu pada waktu kini, yaitu ketika tuturan diujarkan.Berdasarkan konteks tuturan, 
rujukan kata sekarang yang ditemukan pada data penelitian memiliki rentang waktu yang lama, mulai waktu penutur mengujarkan tuturan sampai waktu tidak tentu. Hal ini ditunjukkan oleh data (1) dan data (2) berikut. (1) Dan sekarang terbukti bisa lulus PNS dan kita berani mempertanggungjawabkan.

(2) Fakultas paling favorit dan paling cantik sekarang.

Selanjutnya, pada deiksis waktu nantimemiliki acuan yang bersifat relatif, tergantung pada konteks tuturan. Kata nanti mengacu kepada waktu sesudah tuturan. Hasil penelitian menunjukkan bahwa deiksis waktu bentuk nanti dapat merujuk kepada waktu yang lama setelah tuturan. Penggunaan kata nanti yang memiliki rentang waktu jauh ke depan dipaparkan sebagai berikut.

(3) Saya yakin di kelas ini, tidak semua, tentu nanti akan jadi guru.

Pada data (3) di atas kata nanti merujuk pada waktu yang akan datang, yaitu ketika mahasiswa lulus dari kuliah dan menjadi guru. Berdasarkan konteksnya, kata nanti tersebut mengacu pada beberapa tahun yang akan datang.

(4) Dan nanti saya akan berusaha untuk soal ujian akhir kita lebih ke praktikal.

Deiksis waktu nanti pada data di atas memiliki acuan yang tidak lama setelah tuturan, yakni pada akhir semester. Dengan demikian, kata nanti tersebut rujukannya beberapa minggu setelah tuturan.

(5) Saya akhiri perkuliahan kita sore hari ini, mudah-mudahan ada manfaat yang kalian dapat.

Bentuk hari ini pada data (5) di atas merujuk pada waktu sekarang, yakni saat tuturan tersebut diujarkan. Waktu yang dirujuk adalah mulai dari jam kuliah sampai dengan berakhirnya jam kuliah mata kuliah yang bersangkutan.

Selanjutnya, pada data yang diperoleh juga menunjukkan penggunaan deiksis waktu bulan depan dan minggu depan.Bulan depan digunakan untuk mengacu pada bulan yang akan datang, yaitu bulan setelah bulan dituturkannya ujaran tersebut. Demikian juga dengan minggu depan, bentuk ini digunakan untuk mengacu pada minggu yang akan datang, yakni satu minggu setelah tuturan. Berdasarkan konteksnya, bentuk bulan depan yang terdapat pada data (6) di bawah ini mengacu pada waktu yang akan datang dan tidak tentu, apakah satu bulan setelah bulan ini atau beberapa bulan setelah bulan ini. Penggunaan deiksis waktu minggu depan juga merujuk pada waktu yang akan datang dan tidak pasti. Berdasarkan konteksnya, bentuk tersebut mungkin saja mengacu pada satu minggu setelah tuturan atau beberapa minggu yang akan datang setelah tuturan. Berikut dipaparkan data menyangkut dengan penggunaan kedua bentuk deiksis waktu tersebut.

(6) Saya tidak tahu semester depan atau bulan depan atau minggu depan saya masih dipercaya untuk mengajar di PGSD.

Deiksis waktu kemarin mengacu pada hari sebelum hari ini. Dengan demikian, kemarin sore pada data (7) berikut mengacu pada hari sebelum hari ini di waktu sore. Berdasarkan konteksnya, bentuk tersebut memiliki rentang waktu mulai dari sore hari sebelum hari ini sampai dengan saat tuturan tersebut diujarkan.

(7) Ya, izin. Kemarin sore di kampus.

Berikut adalah data yang mengandung deiksis waktu pada tuturan dosen yang berlatar belakang budaya Jawa.

(1) Oke, hari ini untuk hari ini kita mendiskusikan hasil wawancara kalian kemarin.

(2) Ya kan berarti nanti ada lima kelompok kan?

(3) Salah satu kelompok kayak kemarin lagi ya.

(4) Ya tapi kan kemarin yang wawancara siapa?

(5) Nah sekarang dijelasin aja jangan didengarkan rekamannya tok. 
(6) $\mathrm{Ni}$ bagus ni kalau nanti kalian angkat jadi topik.

(7) Jadi nanti kalau ada yang membutuhkan ambil bahan itu untuk skripsi.

(8) Cukup untuk hari ini, ini kan kemarin ada tugasnya ada lima ya.

(9) Jadi nanti tidak bisa lihat kiri-kanan.

(10) Ingat-ingat ya nanti dikumpulkan.

(11) Hari ini kita mau bahas tentang turunan dan integral.

(12) Jadi nanti ada soal trus dijawab kayak kemarin lagi.

(13) Kalau memang minggu depan tidak ada pertemuan lagi, hari ini kan sudah tercukupi.

(14) Ini kemarin kan ada spidol.

(15) Dari tadi kenapa gak bilang.

Bentuk-bentuk deiksis waktu yang ditemukan pada data tuturan dosen FKIP yang berlatar belakang budaya Jawa adalah hari ini, kemarin, nanti, sekarang, minggu depan, dan dari tadi. Bentuk-bentuk deiksis tersebut memiliki rujukan yang berbeda-beda tergantung pada konteks tuturan. Analisis deiksis waktu tersebut akan dipaparkan di bawah ini.

Deiksis waktu hari ini mengacu pada hari sekarang atau waktu sekarang saat tuturan tersebut diujarkan. Bentuk hari ini memiliki rentang waktu yang berbeda, dapat berarti hari secara keseluruhan mulai dari pagi hingga sore atau waktu tertentu saja. Semua bergantung pada konteks tuturannya. Berikut adalah data penggunaan deiksis waktu menggunakan frasa hari ini.

(1) Oke, hari ini untuk hari ini kita mendiskusikan hasil wawancara kalian kemarin.

(8) Cukup untuk hari ini, ini kan kemarin ada tugasnya ada lima ya.

(11) Hari ini kita mau bahas tentang turunan dan integral.

(13) Kalau memang minggu depan tidak ada pertemuan lagi, hari ini kan sudah tercukupi.
Pada data (1), hari ini mengacu pada waktu sekarang, yakni pada waktu atau pada hari tuturan tersebut diujarkan. Rentang waktu yang ditunjukkan oleh bentuk deiksis tersebut tidak lama, hanya selama jam mata kuliah tersebut. Mata kuliah tersebut sebanyak 2 SKS. Berdasarkan konteksnya, rentang waktu hari ini pada data di atas selama 2 SKS.

Demikian juga pada data (8). Bentuk deiksis waktu hari ini merujuk pada hari ketika jam mata kuliah tersebut selama pembelajaran itu berlangsung. Artinya, deiksis waktu tersebut rentang waktunya tidak lama, beberapa jam saja. Hal yang sama juga ditunjukkan pada data (11). Pada data (11) tersebut, deiksis waktu hari ini memiliki acuan pada saat tertentu saja. Sesuai dengan konteks tuturan, bentuk hari ini memiliki rentang waktu selama proses pembelajaran berlangsung pada mata kuliah yang dimaksud. Hari ini tersebut (data 11) acuannya bukanlah pada hari keseluruhan. Dengan demikian, hari ini mengacu kepada waktu kinipada waktu tuturan diujarkan.

Selanjutnya, acuan yang ditunjukkan oleh data (13) adalah waktu tertentu. Berdasarkan konteks tuturan, hari inimerujuk pada waktu jam kuliah bersangkutan dan mencakup waktu selamaberlangsungnya jam kuliah tersebut pada waktu tuturan tersebut diujarkan.

Bentuk deiksis waktu kemarin diartikan sebagai hari sebelum hari ini. Rujukan dapat berbeda-beda sesuai dengan konteks tuturan. Penggunaan deiksis waktu kemarin diperlihatkan pada data berikut ini.

(1) Oke, hari ini untuk hari ini kita mendiskusikan hasil wawancara kalian kemarin.

(3) Salah satu kelompok kayak kemarin lagi ya.

(1) Ya tapi kan kemarin yang wawancara siapa?

(8) Cukup untuk hari ini, ini kan kemarin ada tugasnya ada lima ya. 
(12) Jadi nanti ada soal trus dijawab kayak kemarin lagi.

(14) Ini kemarin kan ada spidol.

Deiksis waktu kemarin pada data (1) mengacu kepada beberapa hari sebelum tuturan itu diujarkan. Deiksis waktu tersebut mengacu kepada beberapa hari yang lalu. Sesuai dengan konteksnya, kata kemarin tersebut merujuk kepada waktu tidak tertentu.

Pada data (1), kata kemarin merujuk kepada beberapa hari sebelum tuturan. Waktu yang ditunjukkan memiliki rentang waktu yang lama, yakni beberapa minggu sebelum tuturan.

Pada data (3) kata kemarin memiliki memiliki rentang waktu yang pasti. Berdasarkan konteksnya, deiksis waktu kemarin tersebut mengacu pada satu minggu sebelum tuturan, yaitu ketika jam kuliah dimaksud. Dengan demikian, rentang waktunya adalah lama, beberapa hari sebelum tuturan.

Penggunaan kata kemarin yang digunakan dalam tuturan (4) di atas merujuk kepada waktu yang tidak pasti, apakah satu hari yang lalu atau beberapa hari yang lalu. Berdasarkan konteksnya, waktu kemarin yang diperlihatkan pada data (4) di atas merujuk kepada beberapa hari sebelum tuturan itu diujarkan. Deiksis waktu tersebut mengacu kepada waktu yang tidak tertentu dan memiliki rentang waktu yang lama sebelum tuturan. Pada data (8), deiksis waktu kemarin mengacu pada beberapa yang lalu, tepatnya pada saat jam kuliah tersebut pada minggu yang lalu. Berdasarkan konteksnya, tuturan tersebut diujarkan pada hari Kamis sehingga rujukan kata kemarin adalah pada hari Kamis sebelumnya. Dengan demikian, kata tersebut memiliki acuan yang pasti.

Selanjutnya, data (12) menunjukkan penggunaan kata kemarin mengacu pada waktu tidak tentu dan tidak pasti. Rujukan kata tersebut adalah beberapa hari yang lalu setelah tuturan tersebut diujarkan. Demikian juga dengan rujukan yang ditunjukkan pada data (14) di atas. Bentuk deiksis waktu kemarin mengacu pada beberapa hari yang lalu setelah tuturan.

Deiksis waktu nanti memiliki rujukan yang berbeda-beda. Waktu yang ditunjukkan bersifat relatif. Kata nanti mengacu kepada waktu sesudah tuturan. Hasil penelitian menunjukkan bahwa deiksis waktu bentuk nanti merujuk kepada waktu yang lama setelah tuturan atau waktu yang lama dari sekarang (jauh ke depan). Penggunaan kata nanti yang rujukannya jauh ke depan dipaparkan sebagai berikut.

(2) Ya kan berarti nanti ada lima kelompok kan?

(6) Ni bagus ni kalau nanti kalian angkat jadi topik.

(7) Jadi nanti kalau ada yang membutuhkan ambil bahan itu untuk skripsi.

(9) Jadi nanti tidak bisa lihat kiri-kanan.

(10) Ingat-ingat ya nanti dikumpulkan.

(12) Jadi nanti ada soal trus dijawab kayak kemarin lagi.

Kata nanti pada data (2) di atas mengacu pada waktu yang lama dari sekarang, yakni pada pertemuan-pertemuan berikutnya. Rentang waktu kata nanti tersebut adalah selama satu semester. Berdasarkan konteks tuturan, deiksis waktu yang ditunjukkan pada data (2) rujukannya adalah jauh ke depan setelah tuturan. Pada data (6) di atas, deiksis waktu yang digunakan menunjuk pada waktu yang akan datang setelah tuturan. Kata nanti tersebut merujuk kepada waktu yang tidak pasti. Berdasarkan konteks tuturan, penggunaan nanti mempunyai jangkauan waktu yang tidak tertentu.

Kata nanti pada data (7) tersebut dipakai untuk merujuk kepada waktu tertentu. Berdasarkan konteks tuturan, kata tersebut merujuk kepada waktu yang jauh ke depan dan memiliki jangkauan waktu yang luas.Jadi, deiksis waktu nanti pada data tersebut mengacu pada waktu mahasiswa menyusun skripsi pada semester akhir. Selanjutnya, kata 
nanti yang ditunjukkan pada data (9) merujuk kepada waktu jauh ke depan sesudah tuturan. Berdasarkan konteksnya, nanti pada data tersebut menunjukkan rentang waktu yang lama melebihi jangkauan beberapa hari ke depan setelah tuturan, yakni ketika ujian berlangsung. Ujian akan dilaksanakan dua minggu setelah tuturan.

Nanti yang dimaksudkan pada data (10) di atas memiliki jangkauan waktu yang jauh ke depan. Pada konteks tersebut, dosen memberikan latihan kepada mahasiswa dan harus dikumpulkan pada akhir semester. Jadi, deiksis waktu nanti pada data (10) memiliki rentang waktu yang lama. Nanti yang dirujuk pada data (12) di atas menunjukkan waktu yang jauh ke depan. Berdasarkan konteks tuturan, kata nanti mengacu kepada waktu setelah tuturan diuajrkansampai minggu depan pada saat pertemuan berikutnya ketika dosen memberikan kuis..

Kata sekarang memiliki rujukan pada saat penutur mengucapkan tuturan (waktu kini). Hal ini seperti yang ditunjukkan pada data (5) di bawah ini.

(2) Nah sekarang dijelasin aja jangan didengarkan rekamannya tok.

Dalam ujaran tersebut, kata keterangan waktu sekarang mengacu ke detik diujarkannya tuturan tersebut.

Diksis waktu dari tadi mengacu pada waktu sebelum tuturan. Bentukdari tadi memiliki jangkauan waktu yang tidak lama. Berdasarkan konteks tuturan, dari tadi pada data (15) di bawah ini merujuk pada saat dosen memasuki kelas sampai dengan tuturan tersebut diujarkan.

(15) Dari tadi kenapa gak bilang.

\section{SIMPULAN}

Deiksis waktu yang ditemukan pada tuturan dosen FKIP yang berlatar belakang budaya Minangkabau adalah kemarin itu, nanti siang, munggu lalu, minggu yang lalu, tadi, nanti, kemarin, dan sekarang. Deiksis waktu yang ditemukan pada tuturan dosen yang berlatar belakang budaya Tapanuli Selatan adalah sekarang, nanti, hari ini, bulan depan, minggu depan, dan kemarin sore. Deiksis waktu yang ditemukan pada tuturan dosen FKIP yang berlatar belakang budaya Jawa adalah hari ini, kemarin, nanti, sekarang, minggu depan, dan dari tadi.

\section{DAFTAR PUSTAKA}

Cahyono, B.Y., (1995). Kristal-Kristal Ilmu Bahasa. Surabaya: Airlangga Universitas Press.

Halliday, M.A.K., dan Hasan R. (1985). Bahasa, Konteks, dan Teks: Aspek-Aspek Bahasa dalam Pandangan Semiotik Sosial. Terjemahan oleh Asruddin Barori Tou. 1994. Yogyakarta: Gajah Mada University Press.

Kushartanti, dkk. (2005). Pesona Bahasa: Langkah Awal Memahami Linguistik. Jakarta: Gramedia.

Nazir, M. (2003). Metode Penelitian. Jakarta: Ghalia Indonesia.

Purwo, B.K., (1984). Deiksis dalam Bahasa Indonesia. Jakarta: Balai Pustaka.

Pusat Bahasa Depdiknas. (2002). Kamus Besar Bahasa Indonesia (Edisi Ketiga). Jakarta: Balai Pustaka.

P.W.J. Nababan. (1987). Ilmu Pragmatik: Teori dan Penerapannya. Jakarta: Departemen Pendidikan dan Kebudayaan.

Rustono. (1999). Pokok-Pokok Pragmatik. Semarang: IKIP.

Sugiyono. (2008). Metodologi penelitian kualitatif, kualitatif E\&D. Bandung: Alfabeta.

Sumarsono. (2008). Buku Ajar Pragmatik. Singaraja: Undiksha

Yule, G., (1996). Pragmatik. Yogyakarta: Pustaka Pelajar. 